\title{
Planktonic rotifers of a saline-lowland river : the Salado River (Argentina)
}

\author{
N. Neschuk ${ }^{1}$ \\ M. Claps ${ }^{1}$ \\ N. Gabellone ${ }^{1}$
}

Keywords : rotifers, plankton, saline lowland river, Argentina.

Seasonal samples of zooplankton were taken during 1997-1999 at fifteen stations in the Salado River basin, and analysed in order to study the rotifer fauna. Spatio-temporal changes in the rotifer plankton composition were examined in the main channel and its tributaries. The majority of species found are tolerant of a wide range of $\mathrm{pH}$, whereas others prefer neutral to alkaline values. The total rotifer plankton density increased downstream from the headwaters to the middle sector of the river. The associated shallow lakes and tributaries were an important source of species. Variations in density and number of species were shown to be associated with conductivity, and species tolerant of high conductivity conditions were especially prevalent (upper $7,000 \mu \mathrm{S} \mathrm{cm}^{-1}$ ). Rotifer density was influenced by hydrological conditions, which promoted maximum values during low water periods and in the high water condition promoted the incorporation of species from shallow lakes connected with the river during flood events. The species associations found are related to such water parameters as conductivity and nutrient availability and to the presence of ponds and shallow, waterlogged depressions connected in varying extent to the main channel.

\section{Rotifères planctoniques d'une rivière saumâtre de plaine : la rivière Salado (Argentine)}

Mots-clés : rotifères, plancton, rivière saumâtre, Argentina.

Des échantillons saisonniers de zooplancton ont été effectués entre 1997 et 1999 sur 15 sites du bassin versant du fleuve Salado et les Rotifères ont été analysés. Les évolutions spatio-temporelles de cette composante planctonique ont été examinées au niveau du cours d'eau principal et de ses affluents. La majorité des espèces identifiées peut se développer dans des eaux de $\mathrm{pH}$ variable, alors que d'autres préfèrent des conditions entre neutralité et alcalinité. La densité totale augmente entre les secteurs amont et intermédiaires du cours d'eau. Les lacs peu profonds et les affluents sont d'importantes sources d'espèces. Les variations du nombre d'espèces et leur densité sont corrélées à la conductivité des eaux, marquée par un record de tolérance des espèces (au-delà de $7.000 \mu \mathrm{S} \mathrm{cm}^{-1}$ ). Les conditions hydrologiques influencent la densité des Rotifères : les périodes d'étiage induisent les valeurs maximales alors que les crues entraînent l'incorporation d'espèces en provenance des lacs associés au réseau hydrologique. Les associations d'espèces identifiées sont reliées à certains paramètres tels que la conductivité et les nutriments, ainsi qu'à la présence de marais et points d'eau connectés à différents degrés au cours d'eau principal.

\section{Introduction}

One of the most important characteristics of the plankton community in lowland rivers is a significant increase in numerical abundance towards the mouth. This continuous recruitment of organisms is related to the presence of dead zones that are utilised for repro-

\footnotetext{
1. Institute of Limnology «Dr. R. Ringuelet» (CONICET - UNLP), Av. Calchaqui km 23,5 1888 Florencio Varela, Argentina.
}

duction and to the incorporation of inocula from lentic environments within the basins (Pourriot et al. 1997, Astiz \& Alvarez 1998, Akopian et al. 1999, Reckendorfer et. al. 1999). Rotifers are an important component of the plankton in lowland rivers in terms of both specific richness and density (Walker 1992, Admiraal et al. 1994, Pourriot et al. 1997). This predominance is the result of their rapid reproductive capacity during optimal conditions, their short generation time and their ability to develop large populations in eutrophic environments (Ghadouani et al. 1998, Gosselain et al. 1998, Lair et al. 1998). 
To date, the study of planktonic rotifers in the rivers and streams of Buenos Aires province is limited to the contributions of Kuczynski (1984), Modenutti \& Claps (1988) and Modenutti (1991, 1998). The rotifers constitute the main zooplankton group in the lowest sector of Salado River, but their abundance is lower than that recorded in a backwater pond. These associated environments act as sources of inocula (Solari et al. 2002). In this paper, we have performed the first characterisation of the rotifer component of plankton in the Salado River, the main river of the province. Spatio-temporal changes of these plankton components were analysed in the main course as well as in its tributaries. The rotifer assemblages of the Salado River basin were analysed with regard to different geomorphological characteristics and hydrological, physical and chemical conditions.

\section{Sites and methods}

The Salado River is a typical lowland river and the major autochtonous river of Buenos Aires province. It is the southernmost tributary of the Río de la Plata Ba- $\sin$. Its length is approximately $571 \mathrm{~km}$, with a low slope (mean: $0.107 \mathrm{~m} \mathrm{~km}^{-1}$ ). Its watershed is approximately $150,000 \mathrm{~km}^{2}$. The basin includes one of the most important agriculture regions of the country. The headwater sector is characterised by the presence of sedimentary aquifers with high sodium chloride concentrations, which originated during arid periods of the Pleistocene. The effects of this are manifest in the presence of saline streams and saline shallow lakes, which determine the salt balance of the Salado River. In the lower basin, the salinity is reduced during flood periods by the influx of runoff water.

Seasonal samples were obtained during the period March 1997 - May 1999 in fifteen locations (Fig.1) from the headwater sectors to the mouth of Salado river and its main tributaries (Salado, Piñeiro, Saladillo, Saladillo-Vallimanca and Las Flores streams, and an artificial channel : Canal 16).

Temperature $\left({ }^{\circ} \mathrm{C}\right)$, conductivity, $\mathrm{pH}$, dissolved oxygen and turbidity were measured with a Horiba U10 multimeter. The surface velocity of water was measured with floats. Water samples were collected for ana-

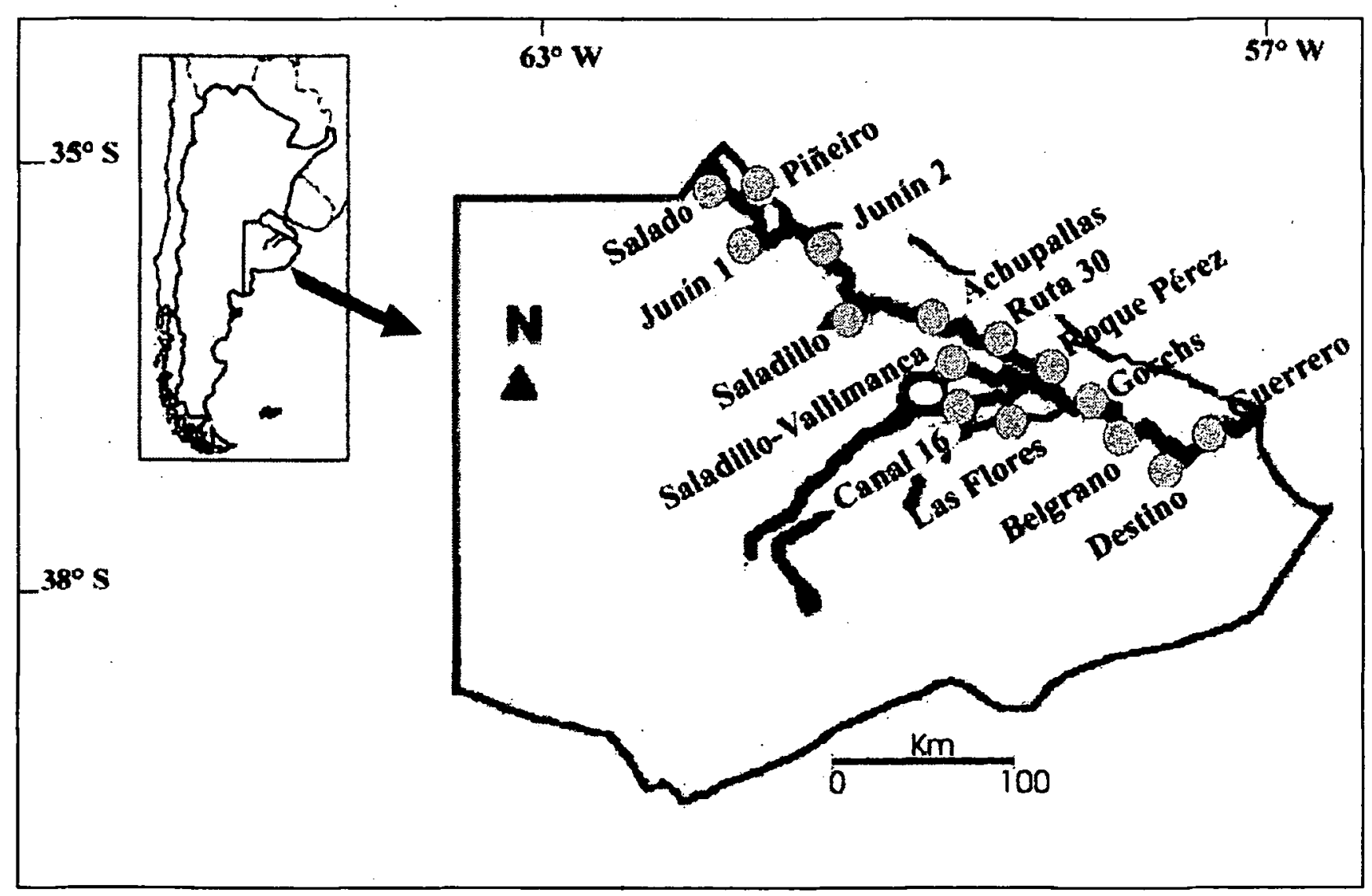

Fig. 1. Situation des sites d'étude. 1 : Rivière Salado; 2 : Rivière Piñeiro; $3:$ Junín-1, $4:$ Junín-2; $5:$ Rivière Saladillo; 6 : Achupallas; 7 : Ruta 30; 8 : Roque Pérez; 9 : Rivière Saladillo-Vallimanca; 10 : Canal 16; 11 : Ruisseau Las Flores; 12 : Gorchs; 13 : Belgrano; 14 : El Destino; 15 : Postrera.

Fig. 1. Location of the study sites. 1 : Salado stream; 2 : Piñeiro stream; $3:$ Junín-1; 4 : Junín-2; 5 : Saladillo stream; 6 : Achupallas; 7 : Ruta 30; 8 : Roque Pérez; 9 : Saladillo-Vallimanca stream, 10 : Canal 16; 11 : Las Flores stream; 12 : Gorchs; 13 : Belgrano; 14 : El Destino;15 : Postrera. 
lysis of total phosphorous (TP) and nitrates plus nitrites. Total phosphorus was determined by the ascorbic acid method after digestion with acidic persulfate (APHA 1995) and nitrates plus nitrites by reduction with hydrazine sulphate (APHA 1995).

Zooplankton rotifers were identified and counted after collecting samples from the middle of the course by sieving $100 \mathrm{~L}$ of subsurface water on $35 \mu \mathrm{m}$ mesh and fixing the material retained in $4 \%$ formaldehyde. Rotifers were counted in a $1 \mathrm{ml}$ Sedgwick-Rafter chamber under a compound microscope. Rotifer identification was based on Koste (1978), Segers (1995) and De Smet (1996).

Correlation coefficients were calculated between some physical-chemical parameters and total rotifer densities. For comparison the rotifer assemblages in the Salado River, Jaccard's index was applied with the statistical package included in Ludwig \& Reynolds (1988).

\section{Results}

In the headwaters, the river receives important water input from shallow lakes (Gómez and Carpincho lakes). This sector is characterised by intermediate conductivity values and the highest nutrient concentrations. The middle sector is characterised by the maximum average conductivity value and intermediate nutrient concentrations. In this sector, the river is connected with shallow lakes during floods (San Miguel del Monte, Las Perdices and Las Encadenadas ponds, among others). The lower sector presents a diminution of conductivity and lower nutrient concentrations than upstream (Table 1). In the mouth sector, the main cour- se is again associated with shallow lakes (San Lorenzo, Esquivel and Las Barrancas, among others) during floods and receive daily influence of the RÌo de la Plata estuary. Compared to the main course, the streams of the sub-basin (Las Flores and Saladillo-Vallimanca) show lower values of conductivity (mean: 2,527 $\mu \mathrm{S} . \mathrm{cm}^{-1}$ ) and nutrient concentrations (mean TP 261.5 $\mu \mathrm{g} \mathrm{L}^{-1}$ and mean nitrates plus nitrites $270.75 \mu \mathrm{g} \mathrm{L}^{-1}$ ).

The Salado River was characterised by alkaline (mean pH: 8.6), oxygenated water (mean dissolved oxygen concentration: $7.7 \mathrm{mg} \mathrm{L}^{-1}$ ) and a relatively high water temperature (mean: $18.7^{\circ} \mathrm{C}$ ) (Table 1 ).

A total of 63 rotifer species were identified throughout the study period. The family Brachionidae was best represented (17 species), with the Lecanidae coming second (ten species). The following species were found in all sampling stations : Colurella colurus, Filinia longiseta, Keratella tropica, Lepadella ovalis, $\mathrm{Po}$ lyarthra vulgaris, Proalides sp. and bdelloideans. Colurella colurus, $L$. ovalis and bdelloideans always presented in low densities. Some species were recorded at all stations except one or two tributaries: Brachionus angularis, $B$. caudatus, $B$. plicatilis, B. pterodinoides, B. urceolaris, Pompholyx sulcata, Synchaeta sp., and Trichocerca pusilla. Other species (Brachionus urceolaris nilsoni, Epiphanes sp., Keratella cochlearis, Lecane hastata, Monommata sp., Mytilina mucronata, $M$. ventralis, and Platyas quadricornis) were unrecorded at headwaters whereas Brachionus satanicus was found exclusively in this sector (Table 2).

Filinia longiseta var. passa, P. sulcata, and Trichocerca tigris were found only in summer whereas Notholca acuminata, $N$. squamula, and Monommata sp. occurred only in low temperature periods.

Table 1. Physical and chemical characteristics (mean values) of 15 sampling stations located in the Salado River basin during period March/97- May/99 (standard desviation in brackets).

Tableau 1. Caractéristiques physico-chimiques (valeurs moyennes) des quinze stations étudiées du bassin de la Rivière Salado entre Mars/97-Mai/99 (déviation standard entre parenthèses).

\begin{tabular}{lcccc}
\hline & Headwaters & Middle sector & Mouth sector & Tributaries \\
\hline Total phosphorus $\left(\mu \mathrm{g} . \mathrm{L}^{-1}\right)$ & $\mathbf{8 2 5 . 8 ( 4 8 9 . 8 )}$ & $468.1(240.9)$ & $316.3(120.6)$ & $383.3(289.2)$ \\
$\mathrm{NO}_{2}-\mathrm{N}+\mathrm{NO}_{3}-\mathrm{N}\left(\mu \mathrm{g} . \mathrm{L}^{-1}\right)$ & $949.1(1185.2)$ & $363.0(501.8)$ & $376.2(329.5)$ & $473.1(660.2)$ \\
Temperature $\left({ }^{\circ} \mathrm{C}\right)$ & $18.9(5.9)$ & $19.1(6.4)$ & $17.8(5.5)$ & $18.8(6.2)$ \\
Dissolved oxygen $\left(\mathrm{mg} . \mathrm{L}^{-1}\right)$ & $7.9(3.0)$ & $7.5(3.5)$ & $7.4(2.3)$ & $8.4(2.6)$ \\
Conductivity $\left(\mu \mathrm{S} . \mathrm{cm}^{-1}\right)$ & $4592.6(2126.2)$ & $5367.6(2367.9)$ & $3767.7(1945.4)$ & $3224.1(2280.4)$ \\
Turbidity $(\mathrm{NTU})$ & $123.8(239.2)$ & $127.6(160.1)$ & $134.0(149.6)$ & $64.1(136.6)$ \\
pH & $9.1(0.3)$ & $8.6(0.4)$ & $8.4(0.4)$ & $8.5(0.4)$ \\
Flow velocity $\left({\left.\mathrm{m} . \mathrm{s}^{-1}\right)}^{0.98(0.7)}\right.$ & $0.9(0.6)$ & $1.2(0.7)$ & $0.8(0.4)$ \\
\hline
\end{tabular}


Table 2. Rotifers founded in the Salado River basin.

Tableau 2. Rotifères récoltés dans le bassin de la Rivière Salado.

\begin{tabular}{|c|c|c|c|c|c|c|c|c|c|c|c|c|c|c|c|}
\hline \multirow[b]{2}{*}{ Species } & \multicolumn{15}{|c|}{ Sampling stations } \\
\hline & 1 & 2 & 3 & 4 & 5 & 6 & 7 & 8 & 9 & 10 & 11 & 12 & 13 & 14 & 15 \\
\hline Amuraeopris fissa (Gosse) & 0 & 1 & 0 & 0 & $\overline{0}$ & 1 & $\overline{1}$ & $\overline{1}$ & 0 & 1 & 0 & 0 & 1 & 0 & 0 \\
\hline Ascomorpha sp. & 1 & 0 & I & 0 & 0 & 1 & 0 & 1 & 0 & l & $\mathbf{0}$ & $\mathbf{0}$ & 1 & -1 & 0 \\
\hline Aspianchna brightwelli (Gosse) & 1 & 0 & 1 & 1 & 1 & 1 & 1 & 1 & 1 & 1 & 1 & $\mathbf{0}$ & 1 & 1 & 1 \\
\hline Brochiomus angularis Gosse & 1 & 0 & 1 & 1 & 1 & 1 & 1 & 1 & 1 & 1 & 1 & 1 & 1 & 1 & 1 \\
\hline B. budapestinensis Daday & 1 & 1 & 1 & 1 & 0 & 1 & 1 & 1 & 1 & 1 & 0 & 1 & 1 & 1 & 1 \\
\hline B. calyciflonus Pallas & 1 & 0 & 1 & 0 & 1 & 1 & 1 & 1 & 1 & 1 & 0 & 1 & 1 & 1 & 1 \\
\hline B. condatus Barrois \& Dadsy & 1 & 0 & 1 & 1 & 1 & 1 & 1 & 1 & 1 & 1 & 1 & 1 & 1 & 1 & 1 \\
\hline B. hovanensis Rousselet & 1 & 0 & 0 & 1 & 0 & $\mathbf{0}$ & 1 & 1 & 0 & 1 & 0 & 0 & 1 & 1 & ] \\
\hline B. plicatitis (O.F.M) & 1 & 0 & 1 & 1 & 1 & 1 & 1 & 1 & 1 & 1 & 1 & 1 & 1 & 1 & 1 \\
\hline B. pterodimoides (Rousselet) & 1 & 1 & 1 & 1 & 1 & 1 & 1 & 1 & 1 & 1 & 0 & 1 & 1 & 1 & 1 \\
\hline B. quadridentatus (Hermanns) & 1 & 0 & 0 & 1 & $\mathbf{I}$ & 1 & 1 & 1 & 1 & 1 & 0 & l & 1 & 1 & $l$ \\
\hline B. satanicus Rousselet & $\mathbf{0}$ & 0 & 1 & 0 & 0 & 0 & 0 & 0 & 0 & 0 & $\mathbf{0}$ & 0 & 0 & 0 & 0 \\
\hline B. urceolaris O.F.M. & 1 & 0 & 1 & $\mathbf{l}$ & 1 & 1 & 1 & 1 & 0 & 1 & 1 & 1 & 1 & 1 & 1 \\
\hline B. urceolaris nilsoni (Ahlstrom) & $\mathbf{0}$ & 0 & 0 & 0 & 0 & 0 & 1 & 1 & 0 & 1 & $\mathbf{0}$ & $\mathbf{0}$ & 1 & 0 & 0 \\
\hline Bdelloideans & 1 & 1 & 1 & 1 & 1 & 1 & 1 & 1 & 1 & 1 & 1 & 1 & 1 & 1 & 1 \\
\hline Colurella colurus (Ehr.) & 1 & 1 & 1 & 1 & 1 & 1 & 1 & 1 & 1 & 1 & 1 & 1 & 1 & 1 & 1 \\
\hline C. uncinata (O.F.M) & 0 & 1 & 1 & 1 & 1 & 1 & 1 & ] & 1 & 1 & 0 & 0 & 0 & 1 & 1 \\
\hline Cephalodella spl & 0 & 0 & $\mathbf{0}$ & 1 & 0 & $\mathbf{0}$ & 0 & 1 & 1 & 1 & 1 & 0 & 0 & 0 & 0 \\
\hline Cephalodella sp2 & 0 & 0 & 1 & 1 & 1 & 1 & 1 & 1 & 1 & 0 & 1 & 0 & 1 & 1 & 0 \\
\hline Cephalodella sp3 & 1 & 0 & 0 & 0 & 0 & 1 & 1 & 0 & 0 & I & $\mathbf{0}$ & 0 & 0 & 0 & 0 \\
\hline Conochilus sp & 0 & 1 & 0 & 1 & 0 & 1 & 1 & 1 & 1 & 1 & 0 & 1 & 1 & 1 & 0 \\
\hline Dicranophones sp & 1 & 0 & 0 & $\mathbf{0}$ & 0 & 1 & 1 & 0 & 1 & 1 & 0 & 0 & 1 & 0 & 1 \\
\hline Epiphanes sp & 0 & 0 & 0 & 0 & 0 & 0 & 1 & 1 & 1 & 0 & 0 & 1 & 1 & 1 & 1 \\
\hline Euchlanis dilatata Ehr. & 0 & 1 & 1 & 0 & $\mathbf{0}$ & 0 & 0 & 1 & 1 & 0 & 0 & $\mathbf{0}$ & $\mathbf{0}$ & 0 & 0 \\
\hline Filinia longiseta (Ehr.) & 1 & 1 & 1 & 1 & 1 & 1 & 1 & 1 & 1 & 1 & 1 & 1 & 1 & 1 & 1 \\
\hline Filinia sp. & 1 & 0 & 1 & 1 & 1 & 0 & 0 & 0 & 0 & 1 & 0 & 1 & 1 & 1 & 0 \\
\hline Gastropus sp & 0 & $\mathbf{0}$ & 1 & 0 & 1 & 0 & 1 & 1 & 0 & 1 & 0 & 1 & 1 & 1 & 0 \\
\hline Hexarthra fennica (Levander) & 0 & 0 & $\mathbf{0}$ & 1 & 0 & 0 & 1 & 0 & 1 & 0 & 0 & 1 & 0 & 1 & 0 \\
\hline Keratella americana Carlin & 1 & 1 & 0 & 0 & $\mathbf{0}$ & 0 & 0 & 1 & 0 & 1 & 0 & 1 & 1 & 1 & 0 \\
\hline$K$ cochleranis (Gosse) & 0 & 0 & 0 & 0 & 1 & $\mathbf{0}$ & 0 & 0 & 1 & 1 & 1 & 1 & 1 & 1 & 1 \\
\hline$K$ lenzi (Haver) & 1 & 0 & 1 & 0 & 0 & $\mathbf{0}$ & 0 & 1 & 0 & 1 & 1 & 0 & 1 & 1 & 0 \\
\hline$K$ tropica (Apstein) & 1 & 1 & 1 & $\mathbf{l}$ & 1 & 1 & 1 & 1 & 1 & 1 & 1 & 1 & 1 & 1 & 1 \\
\hline Lecane arcula Harring & 0 & 0 & 1 & 1 & 1 & 0 & 1 & 1 & 1 & 1 & $\mathbf{0}$ & 1 & 1 & 1 & 1 \\
\hline L bulla (Gosse) & $\mathbf{0}$ & 1 & 0 & 1 & 1 & 1 & 1 & 1 & 1 & 1 & 1 & 0 & 1 & 1 & 1 \\
\hline L closterocerca Schmarda & 0 & 0 & 1 & 1 & 1 & 0 & 1 & 0 & 0 & 1 & 1 & 0 & 1 & 1 & 0 \\
\hline L. hamata (Stokes) & 0 & 1 & 0 & 0 & $\mathbf{0}$ & 1 & 1 & 1 & 1 & 1 & 0 & 0 & 1 & 1 & 0 \\
\hline L hastata (Murray) & 0 & 0 & 0 & 0 & 1 & I & 1 & 1 & 0 & 0 & 0 & 1 & 1 & 1 & 1 \\
\hline L. Luna (OF.M) & 0 & 1 & 0 & 1 & 0 & 1 & 1 & $\mathbf{1}$ & 0 & 0 & 0 & 0 & 1 & 1 & 0 \\
\hline L Lunaris (Ehr.) & 0 & 0 & 0 & 1 & 0 & 0 & 0 & 0 & 0 & 0 & 0 & 0 & 0 & 1 & 0 \\
\hline L mana (Murray) & 0 & 1 & 0 & 0 & $\mathbf{0}$ & $\mathbf{0}$ & 0 & 1 & $\mathbf{0}$ & 0 & 0 & $\mathbf{0}$ & $\mathbf{0}$ & 1 & 0 \\
\hline L papuana (Murray) & 0 & 1 & 0 & 0 & $\mathbf{0}$ & $\mathbf{0}$ & 1 & 0 & 0 & 0 & 0 & $\mathbf{0}$ & $\mathbf{0}$ & 0 & 0 \\
\hline L. pyriformis (Daday) & 1 & 1 & 0 & 0 & $\mathbf{0}$ & 1 & 1 & 1 & 1 & 1 & 1 & 0 & 1 & 1 & 1 \\
\hline Lepadella acuminata (Ehr.) & $\mathbf{0}$ & 1 & 0 & 0 & 0 & 1 & 1 & 1 & 1 & 1 & 0 & 0 & 1 & 0 & 0 \\
\hline L ovalis (OFM) & 1 & 1 & 1 & $\mathbf{1}$ & 1 & 1 & 1 & 1 & 1 & 1 & 1 & 1 & 1 & 1 & 1 \\
\hline L patella (OF.M.) & 1 & $\mathbf{l}$ & 0 & 1 & 0 & 1 & 1 & 1 & 0 & 1 & 0 & $\mathbf{0}$ & $\mathbf{0}$ & 1 & 0 \\
\hline Lophocaris salpina (Ehr.) & 0 & 1 & 0 & 0 & 0 & 1 & & $\mathbf{0}$ & 0 & 0 & 0 & 0 & 1 & 1 & 0 \\
\hline Monommata sp. & 0 & 0 & 0 & 0 & $\mathbf{0}$ & 0 & 0 & 0 & 0 & 0 & 1 & 0 & 1 & 0 & 0 \\
\hline Mytilina mucronata (Ehr.) & 0 & 0 & 0 & 0 & 0 & 0 & 1 & 1 & 0 & 0 & 0 & $\mathbf{0}$ & 0 & 0 & 0 \\
\hline$M$ ventralis (Ehr.) & $\mathbf{0}$ & 0 & 0 & 0 & $\mathbf{0}$ & 0 & 0 & 0 & 0 & 0 & 0 & $\mathbf{0}$ & 0 & 0 & 1 \\
\hline Notholca acuminata (Ehr.) & $\mathbf{0}$ & 0 & 1 & $\mathbf{0}$ & $\mathbf{0}$ & 1 & 1 & 1 & 1 & 1 & $\mathbf{0}$ & 0 & 1 & 1 & 1 \\
\hline N. squamila (O.F.M) & 1 & 0 & 1 & 0 & $\mathbf{1}$ & 0 & 1 & 1 & 0 & 1 & 0 & 1 & 1 & 1 & 1 \\
\hline Platyas quadricomis (Ebr.) & 0 & 0 & 0 & 0 & 1 & 1 & 1 & 1 & 0 & 1 & 0 & 1 & 1 & 1 & 1 \\
\hline Polyarthra vulgaris Carlin & 1 & 1 & 1 & 1 & 1 & $\mathbf{l}$ & 1 & 1 & 1 & 1 & 1 & 1 & 1 & 1 & 1 \\
\hline Phompholyx sulcata Hudson & 1 & 0 & 1 & 1 & 1 & 1 & 1 & 1 & 1 & 1 & 0 & 1 & 1 & 1 & 1 \\
\hline Proales sigmoidea (Skarikov) & 1 & $\mathbf{0}$ & 0 & $\mathbf{l}$ & $\mathbf{0}$ & $\mathbf{0}$ & 1 & 1 & 1 & 1 & 0 & $\mathbf{0}$ & 1 & $\mathbf{0}$ & 0 \\
\hline Proales sp. & 1 & 0 & 0 & 1 & 0 & 1 & 1 & 1 & 1 & 1 & 1 & $\mathbf{0}$ & 1 & 1 & 1 \\
\hline Proalides sp & 1 & 1 & 1 & $\mathbf{l}$ & 1 & 1 & 1 & 1 & 1 & 1 & 1 & 1 & 1 & 1 & 了 \\
\hline Synchoeta sp & 1 & 0 & 1 & 1 & 1 & 1 & 1 & 1 & 1 & 1 & 1 & 1 & 1 & 1 & 1 \\
\hline Testudinella patina (Hermanns) & 1 & 1 & 0 & 1 & 1 & 0 & 1 & 1 & 1 & 1 & 0 & 1 & 1 & 1 & $\mathbf{l}$ \\
\hline Testucinella sp. & $\mathbf{0}$ & 0 & 1 & 0 & 1 & 0 & 0 & $\mathbf{0}$ & 0 & 0 & 0 & 0 & 0 & 0 & 1 \\
\hline Trichocerca cylindrica (Imhof) & 1 & 1 & 1 & $\mathbf{l}$ & 1 & 1 & 1 & 1 & 0 & 0 & 0 & 0 & $\mathbf{0}$ & 1 & 0 \\
\hline T. pusilla (Lauterbom) & 1 & 0 & 1 & 1 & 1 & 1 & 1 & 1 & 1 & 1 & 1 & 了 & 1 & 1 & 1 \\
\hline T. ratus (O.F.M.) & 1 & 1 & 1 & 1 & 1 & 1 & 1 & 1 & 1 & 1 & 1 & 1 & 1 & 1 & 1 \\
\hline T. stylata (Gosse) & 1 & 0 & 1 & 1 & 1 & 1 & 1 & 1 & 1 & 1 & 1 & 0 & 1 & 1 & 1 \\
\hline T. tigris (OF.M.) & 0 & 0 & 0 & 0 & 0 & 0 & 0 & 0 & 0 & 1 & 0 & 1 & 1 & 1 & 1 \\
\hline
\end{tabular}

1: Salado stream; 2: Pifieiro stream; 3: Junin-1; 4: Junin-2; 5: Saladillo stream; 6: Achupallas; 7: Ruta 30, 8: Roque Pérez 9: Saladillo-Vallimanca stream, 10: Canal 16; 11:Las Flores stream; 12: Gorchs; 13: Belgrano; 14: Destino; 15: La Postrera. 


\section{HEADWATERS}
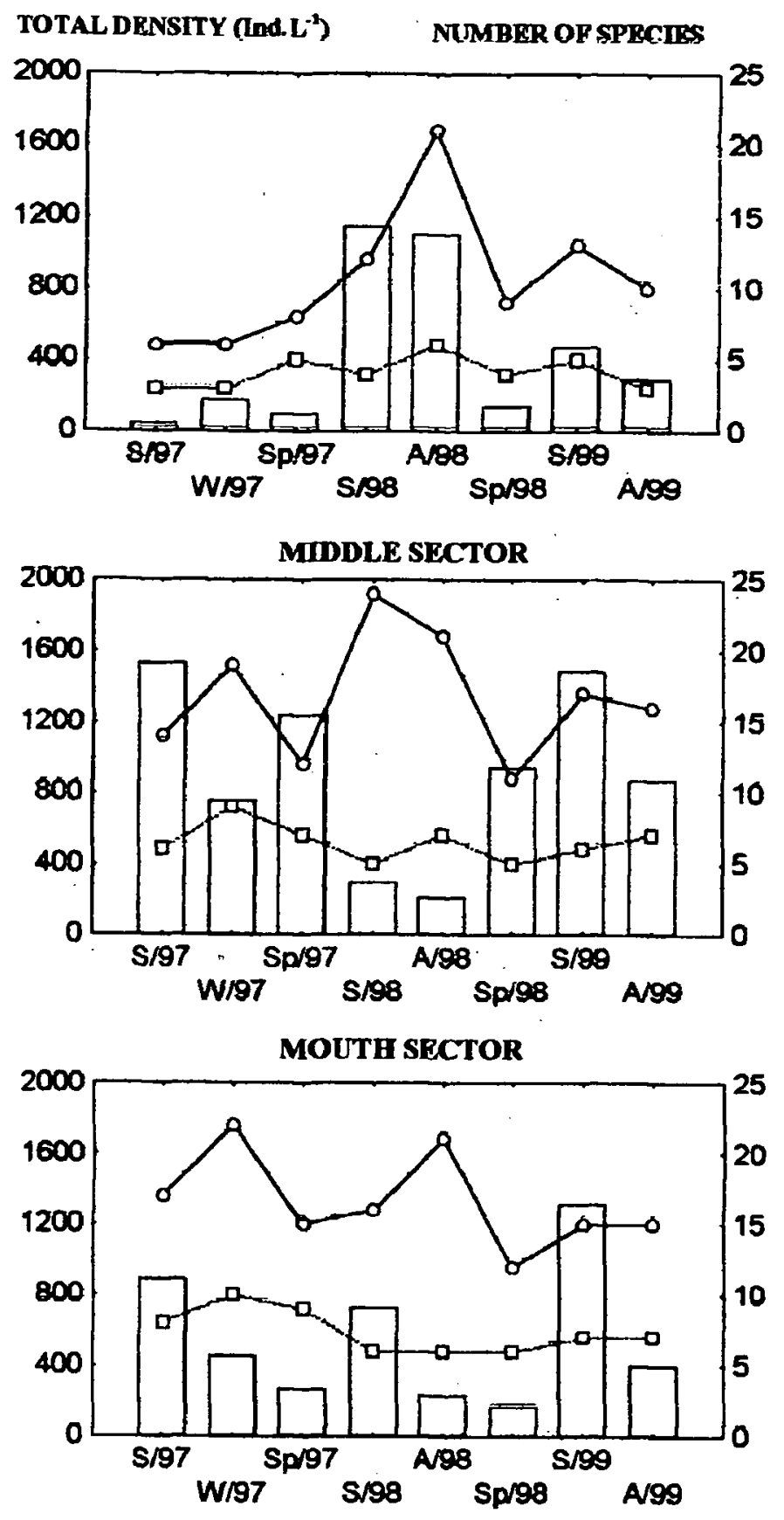

TRIBUTARIES

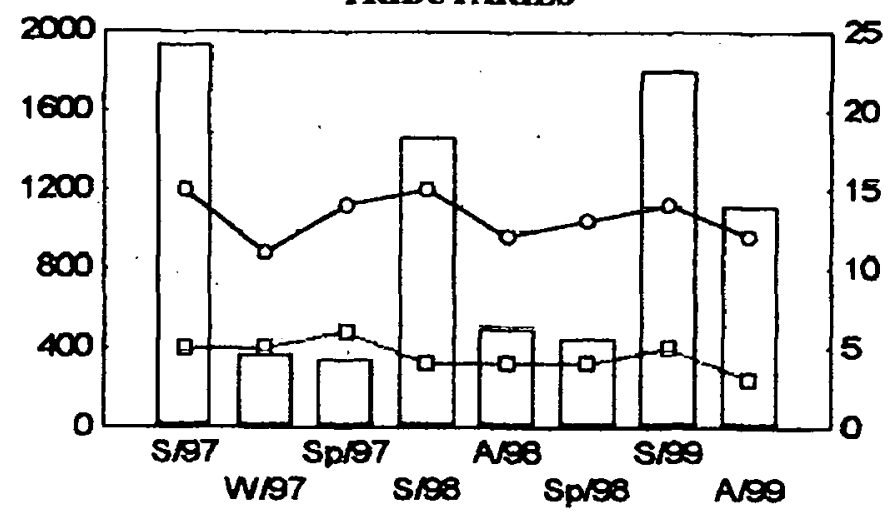

Fig. 2. Variations saisonnières de la moyenne de la densité totale des Rotifères (barres), de la richesse spécifique totale (ligne avec cercles) et du nombre de Brachionidés (ligne avec carrés) dans la Rivière Salado.

Fig. 2. Average seasonal variation of rotifer total density (bars), total species richness (line with circles) and the number of Brachionidae species (lines with squares) of the Salado River.
The total density fluctuated between 10 and 4,250 ind. $\mathrm{L}^{-1}$. The maximum abundance was observed during low waters (summer 1997 and 1999), particularly in the middle river sector and the Saladillo-Vallimanca stream. The headwater sector showed a mean density of 442 ind. $L^{-1}$, with the mean maximum $(1,145$ ind. $\mathrm{L}^{-1}$ ) in summer 1998 and the mean minimum (47 ind. $\mathrm{L}^{-1}$ ) in summer 1997 (Fig. 2). The most important species in this sector were $B$. angularis, $B$. caudatus, $B$. plicatilis, $B$. pterodinoides, $F$. longiseta, $K$. tropica, and $P$. vulgaris. An increase in abundance was observed at the middle sector (mean: 928 ind. $\mathrm{L}^{-1}$ ), with the highest mean value in summer 1997 (1,525 ind. $\left.\mathrm{L}^{-1}\right)$ and the lowest mean value in autumm 1998 (212 ind. $\mathrm{L}^{-1}$ ) (Fig. 2). The most conspicuous species in the middle sector were $B$. angularis, $B$. budapestinensis, $B$. calyciflorus, $B$. caudatus, $B$. plicatilis, $B$. pterodinoides, $F$. longiseta, $K$. tropica and $P$. sulcata. In the mouth sector, density decreased relative to that of the middle one (mean: 557 ind. $\mathrm{L}^{-1}$ ), although the significant differences were observed only at the last sampling stations (Destino and La Postrera). This phenomenon was more evident in summer 1998 and summer 1999. At Belgrano station (the upstream station of the lower sector), the densities were 1,403 and 1,908 ind. $\mathrm{L}^{-1}$, respectively. Conversely, the densities at La Postrera were 404 and 908 ind. $L^{-1}$, respectively. The mean maximum $\left(1,317\right.$ ind. $\left.\mathrm{L}^{-1}\right)$ was observed in summer 1999 and the mean minimum (168 ind. $L^{-1}$ ) in spring 1998 (Fig. 2). The relevant species were $B$. angularis, B. caudatus, B. plicatilis, $K$. tropica and Synchaeta sp. In the tributaries, the mean density was 956 ind. $\mathrm{L}^{-1}$, with mean maximum value $\left(1,927\right.$ ind. $\left.\mathrm{L}^{-1}\right)$ in summer 1997 and the minimum one (341 ind. $\mathrm{L}^{-1}$ ) in spring 1997 (Fig. 2). Brachionus angularis, B. caudatus, $B$. plicatilis, $F$. longiseta and $K$. tropica were most numerous at the tributaries.

The mean maximum of specific richness for the entire basin was recorded in winter 1997 and summer 1998 (more than 20 species), whereas the minimum occurred in winter 1997 and summer 1997 (six species). The middle river sector had the highest value of specific richness in summer of 1998 (29 species). Moreover, a tributary (Saladillo-Vallimanca stream) showed high values in summer 1998 (24 species) and winter 1997 ( 28 species). The number of species belonging to Brachionidae increased downstream from the headwaters to the mouth sector, with mean maximum in winter 1997 and spring 1997 (ten and nine species, respectively). Extremely low numbers of species were observed (Fig. 2) in the headwaters in summer of 1997 (two species: $B$. angularis and $B$. plicatilis). 


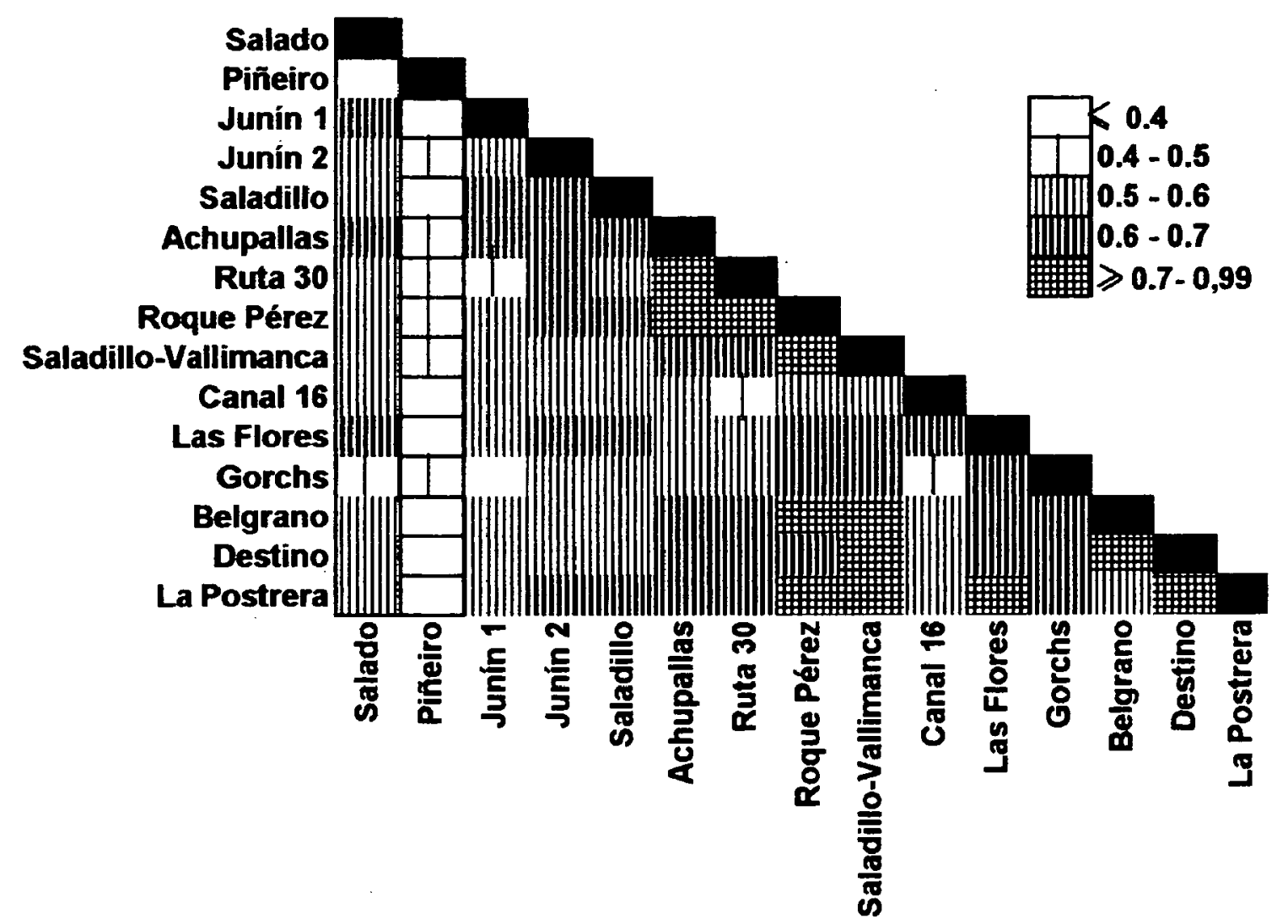

Fig 3. Matrice d'affinité des associations d'espèces avec l'application de l'indice de Jaccard.1: Rivière Salado; 2: Rivière Piñeiro; 3: Junín-1, 4: Junín-2; 5: Rivière Saladillo; 6: Achupallas; 7: Ruta 30; 8: Roque Pérez; 9:Rivière Saladillo-Vallimanca;10: Canal 16; 11:Rivière Las Flores; 12: Gorchs; 13: Belgrano; 14: El Destino; 15: Postrera.

Fig. 3. Affinity matrix of rotifer assemblages in the Salado River basin based on Jaccard index.1: Salado stream; 2: Piñeiro stream; 3: Junín-1; 4: Junín-2; 5: Saladillo stream; 6: Achupallas; 7: Ruta 30; 8: Roque Pérez; 9: Saladillo-Vallimanca stream, 10: Canal 16; 11:Las Flores stream; 12: Gorchs; 13: Belgrano; 14: El Destino;15: Postrera.

The total density was positively correlated with concentrations of total phosphorus in Ruta 30 $(r=0.95, p<0.05)$, Las Flores $(r=0.88, p<0.05)$ and Belgrano ( $r=0.81, p<0.05)$. A positive significant correlation was observed with conductivity in tributaries and one of the sampling stations at the middle sector: Saladillo-Vallimanca $(r=0.80, p<0.05)$, Canal 16 $(r=0.91, p<0.05)$, Las Flores $(r=0.98, p<0.05)$ and Gorchs $(r=0.79, p<0.05)$ while a negative significant correlation was obtained in Piñeiro stream $(r=-0.98$, $\mathrm{p}<0.05$ ).

According to the faunistic affinities calculated with the Jaccard index, it was possible to identify significant associations among the sampling stations located within the middle sector and also among those in the lower zone. Sampling stations in the middle sector (Achupallas, Ruta 30 and Roque Pérez) formed a group with 70 per cent affinity. These sampling stations have a faunistic affinity with those located at the mouth sector (index values between 0.60 and 0.70 ). Also, one of the main tributaries (Saladillo-Vallimanca) was associated with stations located in the lower ri- ver sector (values > 0.70). In Las Flores stream, the rotifer composition was similar to that observed in the middle and low sectors of the Salado River as well as those recorded in the headwaters. The Piñeiro stream had the lowest faunistic affinity with all sampled sites (Fig. 3).

\section{Discussion}

The plankton of the Salado River basin is characterised by a high number of rotifer species. The specific richness was found to be higher than other lowland river of the province - Samborombón River- (Modenutti 1998) and environments from Santa Fe province - Salado River and Santa Fe River - (José de Paggi \& Paggi 1998). Moreover, it is similar to that reported for the Delta subbasin belonging to the Río de la Plata estuary basin (Modenutti \& Claps 1988). As in these mentioned water bodies, the family Brachionidae has the highest number of species, followed by Lecanidae. The majority of the species of Lecane found are considered euryoic or tolerant to saline conditions (Miracle et al. 
1995, Segers 1995). Brachionus species and K. tropica were the most abundant rotifers during the study period. The majority of the species found can develop in waters with a wide range of $\mathrm{pH}$, whereas others prefer neutral to alkaline values. Variations in species number and density are associated with the river conductivity, since salinity is a limitation for rotifers (Guisande \& Toja 1988, Green 1993, Modenutti 1998). The rotifer populations in the Salado River can tolerate higher conductivity values (upper $7,000 \mu \mathrm{S} \mathrm{cm}^{-1}$ ) than those cited by José de Paggi (1989) as harmful for rotifers in lotic and lentic environments of north-western Argentina. With conductivity values of $7,000 \mu \mathrm{S} \mathrm{cm}^{-1}, B$. plicatilis and $B$. angularis were recorded with others species like $K$. tropica, Hexarthra fennica, B. caudatus and $B$. urceolaris, all of them reported as tolerant to high conductivity or to salinity variations. In this condition, $B$. plicatilis and $B$. angularis were abundant, whereas the other mentioned species were less common than in other river sectors with lower salinity values. A decrease in specific richness, total density and the unique presence of $B$. plicatilis, $K$. tropica and $H$. fennica were all observed where conductivity was at its maximum value $\left(11,200 \mu \mathrm{S} \mathrm{cm}^{-1}\right)$.

The number of species differed between the main river channel and its tributaries, with maximum values in the middle sector and one affluent (Saladillo-Vallimanca stream). The lowest specific richness was recorded in the headwaters. Tributaries such as Piñeiro stream and Canal 16 showed the lowest faunistic affinity with the other sampling stations, because their assemblages were characterised by dominant Lecane and low species diversity respectively. In the Piñeiro stream, the predominance of lecanids (mainly tychoplanktonic) was related to the presence of aquatic macrophytes (Althernantera philoxeroides, Typha sp., Scirpus californicus) that are favoured by the shallowness of the stream and its low water velocity (average : $0.19 \mathrm{~m} \mathrm{~s}^{-1}$ ). The scarcity of rotifers at the Canal 16 station could be related to its relatively high water velocity compared to other sampling stations (mean : $1.3 \mathrm{~m} \mathrm{~s}^{-1}$ ).

In the headwaters, the total density was low compared to the other sectors and correlated negatively (non significant) with nutrient availability. This phenomenon could be associated with high nutrient concentrations that favour blooms of non-palatable cyanophyte algae (Neschuk et al. in press) and may therefore reflect anthropogenic impacts on this section of river (Neschuk et al., 2000). Total density and specific richness both show downstream increases from the headwaters to the middle river sector, whereas the same two variables decrease from the middle to the mouth. A similar phenomenon was also observed by Pourriot et al. (1997) in the Marne River, where it was attributed to several factors (decrease of food resources, low water conditions and dredging of the channel). In the Salado River, the decrease in rotifer density could be related to an increase of slope $\left(0.54 \mathrm{~m} \mathrm{~km}^{-1}\right)$ in the beginning of the lower sector (downstream of Belgrano station) and the consequent increase in water velocity. Furthermore, the fish predation on plankton (Jerez \& Christiansen 1987, Cardone \& Castello 1994) in this sector is enhanced due to the presence of estuarine species such as gray mullet (Mugil sp).

Rotifer density is also influenced by hydrological conditions, which promote maximum abundance during low water periods. In contrast, the decrease of density during flood periods is the result of dilution (José de Paggi 1981, Vásquez \& Sánchez 1984, Modenutti \& Claps 1988, Modenutti 1998, José de Paggi \& Paggi 1998). The species diversity reaches a maximum in flood periods and it is reduced considerably during low and middle water periods (Vásquez 1984). High water conditions promote the incorporation of species from shallow lakes connected with the river during flood events, whereas only the typical riverine species were found during low and middle water conditions.

In agreement with the results obtained by Saunders \& Lewis (1988) and Akopian et al. (1999) in other lowland rivers, the associated shallow lakes and the tributaries of the Salado River are an important source of species. This phenomenon is reflected in the increase of specific richness downstream of these shallow lakes and has been reported in other river systems (José de Paggi 1981, Pourriot et al. 1997, Astíz \& Alvarez 1998 ) as well as in the lower sector of the Salado River (Solari et al., 2002) .

Brachionus angularis, B. budapestinensis, B. calyciflorus, B. caudatus, B. pterodinoides, B. plicatilis and $B$. urceolaris are dominant in sections of river with high salinity and nutrient values. This is in agreement with the results of Guisande \& Toja (1988) in the Guadalquivir River.

Some perennial species (such as B. caudatus, B. calyciflorus, $K$. tropica, and $F$. longiseta) are typical of eutrophic environments (Ghadouani et al. 1998) and are indicative of the trophic state of the Salado River.

In spite of the lowland river characteristics of the Salado River, the density of rotifers diminishes abruptly in the lower stretch of the mouth sector. This divergence with the usual potamoplankton pattern could be related to the notable increase of slope, which has the effect of destabilising the whole river sector. 
Our results lead us to the conclusions that the rotifer assemblages in the Salado River are associated with the hydrological cycle and the great spatial and temporal heterogeneity of river. The species associations are related to such water parameters as conductivity and nutrient availability, and to the presence of ponds and shallow waterlogged depressions with variable degrees of connectedness to the main channel.

\section{Acknowledgments}

To Unidad Proyecto Río Salado for its assistance in the field work. Lic. N. Neschuk holds a fellowship from the University of La Plata. Argentinean Agency for Science and Technology Promotion (ANPCyT) (Grant PMT-PICT 0409) and the University of La Plata (Grant N208) funded this work. This investigation includes part of the first author's Doctoral Thesis. To Dr. F. Kaisin for the French translation of abstract.

Scientific Contribution $N^{\circ} 727$ of Institute of Limnology Dr R. Ringuelet.

\section{References}

Admiraal W., Breebaart L., Tubbing J., Van Zanten B. de Ruijter Van Steveninck E. \& Bijkerk R. 1994. - Seasonal variation in composition and production of planktonic communities in the lower River Rhine. Freshwater Biology, $32: 519-531$.

Akopian M., Garnier J. \& Pourriot R. 1999. - A large reservoir as a source of zooplankton for the river: structure in the population and influence of fish predation. J. Plankton Res., 21 : 285-297.

American Public Health Association 1995. - Standard Methods for the Examination of Water and Wastewater, 19th edition. Washington, DC.

Astiz S. \& Alvarez H. 1998. - El zooplancton en el Alto y Medio RÌo Orinoco, Venezuela. Acta científica Venezolana, 49 : 5-19.

Cardone L \& Castello F. 1994. - Relative importance of plankton and benthos as food sources for Mugil cephalus and Liza ramada in Israeli semi-intensive fish pond. Isr. J. Aquacult. Bamidgeh., 46 (4) : 197-202.

De Smet W. 1996. - Rotifera volume 4: The Proalidae (Monogononta). In: Dumont, H. (Coord. Ed.), Guides to the identification of the microinvertebrates of the continental waters of the World, SPB Academic Publishing. 102 pp.

Ghadouani A., Pinel Alloul B., Zhang Y. \& Prepas E. 1998. - Relationships between zooplankton community structure and phytoplankton in two lime-treated eutrophic hardwater lakes. Freshwater Biology, 37. : 775-790.

Gosselain V., Viroux L. \& Descy J. 1998. - Can a community of small-bodied grazers control phytoplankton in rivers?. Freshwater Biology, 39 : 9-24.

Green J. 1993. - Zooplankton associations in East African lakes spanning a wide salinity range. In: Hulbert, S.H. (Ed.), Saline Lakes V, Hydrobiologia, $267: 249-256$.

Guisande C. \& Toja J. 1988. - The dynamics of various species of the genus Brachionus (Rotatoria) in the Guadalquivir River. Arch. Hydrobiol., 112 : 579-595.

Jerez B \& Christiansen H. 1987. — Estudio anatómico e histológico de la lisa (Mugil liza) de la laguna Mar Chiquita y breves comentarios sobre la alimentación. Pub. Com. Tec. Mixta. Frente Marit. Argent.- Urug., 3 : 79-91.
José de Paggi S. 1981. - Variaciones temporales y distribución horizontal del zooplancton en algunos cauces secundarios del río Paran medio. Stud. Neotropical Fauna \& Environm., 16 : 185 199.

José de Paggi, S. 1989. - Rotíferos de algunas provincias del noroeste Argentino. Rev. Hydrobiol. Trop., 22 : 223-238

José de Paggi, S. \& Paggi, J. 1998. - Zooplancton de ambientes acuáticos con diferente estado trófico y salinidad. Neotrópica, 44 : 95 106.

Koste W. 1978. - Rotatoria. Die Rädertiere Mitteleuropas. Ein Bestimmungswerk, begründet von Max Voigt. Überordung Monogononta. 2nd ed. I Textband, 673 pp, II Tafelband, 234 Taf., Gebr. Borntraeger, Berlin, Stuttgart.

Kuczynski D. 1984. - Zooplancton (especialmente rotíferos) del río Reconquista (provincia de Buenos Aires). Physis (Sec.B), 42 : 1-7

Lair N., Reyes-Marchant P. \& Jacquet V. 1998. — Développement du phytoplancton, des Ciliés et des Rotifères sur deux sites de la Loire moyenne (France), en période d'étiage. Annls. Limnol,, 34 : 35-48.

Ludwig J. \& Reynolds J. 1988. - Statistical Ecology. A primer on methods and computing. John Wiley \&.Sons, USA. 337 p.

Miracle M., Alfonso M., Vicente E. \& Koste W. 1995. - Rotifers of spring pools in the coastal marshland of Albufera of Valencia Natural Park. Limnética, $11: 39-47$

Modenutti B. \& Claps M. 1988. - Monogononta rotifers from plankton and periphyton of pampasic lotic environments. Limnologica, 19 : 167-175.

Modenutti B. 1991. - Zooplancton de ambientes lóticos de la Subcuenca Delta del Río Paraná, Buenos Aires, Argentina. Iheringia (Zool.), $71: 67-80$.

Modenutti B. 1998. - Planktonic rotifers of Samborombón River Basin (Argentine) Hydrobiologia, 387/388 : 259-265.

Neschuk N., Gabellone N. \& Claps M. 2000. - Caracterización espacial del Río Salado (Buenos Aires) mediante concentraciones de fósforo total. Diversidad y Ambiente, 1 : 13-19.

Neschuk N., Claps M. \& Gabellone N. (in press) - Fitoplancton del Río Salado (Buenos Aires, Argentina): una caracterización espacial estacional. Anales IV Congreso Latinoamericano e Iberoamericano de Ficología.

Pourriot R., Rougier C. \& Miquelis A. 1997. - Origin and development of river zooplankton : example of the river Marne. Hydrobiologia, 345 : 143-148.

Reckendorfer W., Keckeis H., Winkler J. \& Schiemer F. 1999. Zooplankton abundance in the River Danube, Austria: the significance of inshore retention. Freshwater Biology, 41 : 583-591.

Saunders J. F. \& Lewis W. 1988. - Zooplankton abundance in the Caura River, Venezuela. Biotropica, 20 : 206-214.

Segers H. 1995. - Rotifera volume 2: The Lecanidae (Monogononta). In : Dumont H. (Coord. Ed.) : Guides to the identification of the microinvertebrates of the continental waters of the World. SPB Academic Publishing. 226 pp.

Solari L., Claps M. \& Gijellone N. 2002. - River backwater pond interactions in the lower basin of the Salado River (Buenos Aires, Argentina). Arch. Hydrobiol. Suppl. Large Rivers, 41 : 99-119.

Vásquez E. 1984. - Estudio de las comunidades de rotíferos del Orinoco Medio, Bajo Caroni y algunas lagunas de inundación (Venezuela). Mem. Soc. Cienc. Nat. La Salle, 121 : 95-108.

Vásquez E \& Sánchez L. 1984. - Variación estacional del plancton en dos sectores del río Orinoco y una laguna de inundación adyacente. Mem. Soc. Cienc. Nat. La Salle, 121 : 11-33.

Walker K. 1992. - The River Murray, Australia: a semiarid lowland river. In Calows P. \& Petts G. (Eds.), The River Handbook. 1. Blackwell Scientific. Publishers, Oxford : 472-492. 